\title{
Sulfur compounds block MCP-1 production by Mycoplasma fermentans-infected macrophages through NF-KB inhibition
}

Francesca Benedetti ${ }^{1,2}$, Sergio Davinelli ${ }^{1,3}$, Selvi Krishnan ${ }^{1}$, Robert C Gallo ${ }^{1}$, Giovanni Scapagnini ${ }^{3}$, Davide Zella ${ }^{1}$ and Sabrina Curreli $i^{*}$

\begin{abstract}
Background and aims: Hydrogen sulfide $\left(\mathrm{H}_{2} \mathrm{~S}\right)$, together with nitric oxide $(\mathrm{NO})$ and carbon monoxide $(\mathrm{CO})$, belongs to a family of endogenous signaling mediators termed "gasotransmitters". Recent studies suggest that $\mathrm{H}_{2} \mathrm{~S}$ modulates many cellular processes and it has been recognized to play a central role in inflammation, in the cardiovascular and nervous systems. By infecting monocytes/macrophages with Mycoplasma fermentans (M.F.), a well-known pro-inflammatory agent, we evaluated the effects of $\mathrm{H}_{2} \mathrm{~S}$.

Methods: M.F.-infected cells were analyzed by ELISA and real time RT-PCR to detect the M.F. effects on MCP-1 and on MMP-12 expression. The role of two different $\mathrm{H}_{2} \mathrm{~S}$ donors (NaHS and GYY4137) on MF-infected cells was determined by treating infected cells with $\mathrm{H}_{2} \mathrm{~S}$ and then testing the culture supernatants for MCP-1 and on MMP-12 production by ELISA assay. In order to identify the pathway/s mediating $\mathrm{H}_{2} \mathrm{~S}$ - anti-inflammatory activity, cells were also treated with specific pharmaceutical inhibitors. Cytoplasmic and nuclear accumulation of NF-kB heterodimers was analyzed.

Results: We show that $\mathrm{H}_{2} \mathrm{~S}$ was able to reduce the production of pro-inflammatory cytokine MCP-1, that was induced in monocytes/macrophages during M.F. infection. Moreover, MCP-1 was induced by M.F. through Toll-like receptor (TLR)-mediated nuclear factor-KB (NF-KB) activation, as demonstrated by the fact that TLR inhibitors TIRAP and MyD88 and NF-KB inhibitor IKK were able to block the cytokine production. In contrast $\mathrm{H}_{2} \mathrm{~S}$ treatment of M.F. infected macrophages reduced nuclear accumulation of NF-KB heterodimer p65/p52.
\end{abstract}

Conclusions: Our data demonstrate that under the present conditions $\mathrm{H}_{2} \mathrm{~S}$ is effective in reducing Mycoplasma-induced inflammation by targeting the NF-KB pathway. This supports further studies for possible clinical applications.

Keywords: Hydrogen sulfide $\left(\mathrm{H}_{2} \mathrm{~S}\right)$, NaHS, GYY4137, MCP-1, Mycoplasma fermentans, Monocytes/macrophages, NF-kB

\section{Background}

Hydrogen sulfide $\left(\mathrm{H}_{2} \mathrm{~S}\right)$, regarded for decades as a toxic gas, is a ubiquitous gas produced endogenously in the human body and is included in the family of gasotransmitters, together with nitric oxide (NO) and carbon monoxide (CO) [1]. $\mathrm{H}_{2} \mathrm{~S}$ has been implicated in several physiological and pathological contexts including oxidative stress regulation via scavenging reactive oxygen species (ROS), inflammation, vasodilation and neuronal survival [2]. As a gaseous signaling molecule, $\mathrm{H}_{2} \mathrm{~S}$ diffuse

\footnotetext{
* Correspondence: SCurreli@ihv.umaryland.edu

${ }^{1}$ Institute of Human Virology, University of Maryland School of Medicine, Baltimore, MD 21201, USA

Full list of author information is available at the end of the article
}

freely across cell membranes in a receptor-independent manner and activate various cellular targets. Its effects on the cell viability, proliferation, activation, cytokines secretion and cell adhesion have been investigated in many different cell types [3]. $\mathrm{H}_{2} \mathrm{~S}$ has been widely demonstrated to have cardio-protective effects [4], pro-angiogenic [5] and vasorelaxing effects [6] both in in vivo and in vitro experiments. Also $\mathrm{H}_{2} \mathrm{~S}$ mediates KATP channel opening [7], it has inhibitory effect on platelet aggregation [8] and antiapoptotic [9] and cytoprotective effects [10].

The precise role of $\mathrm{H}_{2} \mathrm{~S}$ in inflammation is still far from clear: in fact it may have pro- or anti- inflammatory effects under different conditions [11]. These discrepancies may reflect the varying effects of a dose-response relationship. 
Several studies have demonstrated that $\mathrm{H}_{2} \mathrm{~S}$ donors, in addition to suppressing leukocyte adherence to the vascular endothelium and infiltration to the sites of inflammation [12], can reduce the expression of several pro-inflammatory cytokines. Indeed, $\mathrm{H}_{2} \mathrm{~S}$ inhibits the activation of the transcription factor nuclear factor- $\kappa \mathrm{B}(\mathrm{NF}-\mathrm{k} \mathrm{B})$, essential for the activation of most pro-inflammatory genes, in murine macrophages RAW264.7 cell line following exposure to bacterial endotoxin and blocks the increase of inducible nitric oxide synthase (iNOS) expression and NO production [13]. Moreover $\mathrm{H}_{2} \mathrm{~S}$ inhibits IkB- $\alpha$ degradation and thereby NF- $\mathrm{kB}$ translocation to the nucleus in HUVEC cells stimulated with tumor necrosis factor- $\alpha$ (TNF- $\alpha$ ) [14] and in astrocytes stimulated with LPS [15]. Similarly, $\mathrm{H}_{2} \mathrm{~S}$ inhibits endotoxin-induced upregulation of iNOS expression, NO production and TNF- $\alpha$ expression in cultured microglia. These effects were attributed at least in part to the suppression by $\mathrm{H}_{2} \mathrm{~S}$ of endotoxin-induced p38 mitogen-activated protein (MAP) kinase phosphorylation [16]. Administration of $\mathrm{H}_{2} \mathrm{~S}$ to LPS-injected rats resulted in the activation of STAT3, which is known to regulate the expression of many genes that mediate cell survival, proliferation and angiogenesis [17]. Furthermore $\mathrm{H}_{2} \mathrm{~S}$ administration induces the activation and the nuclear localization of the transcription factor NF-E2-related factor-2 (Nrf-2) in ischemic rat hearts [18]. Nrf-2 is a master regulator of antioxidant transcriptional responses with a protective role in the lungs, mediated through the activation of antioxidant and cytoprotective genes [19]. Moreover $\mathrm{H}_{2} \mathrm{~S}$ increases $\mathrm{NO}$ production with consequential down-regulation of the pro-angiogenic cytokine VEGF (vascular endothelial growth factor) in human keratinocytes [20].

Mycoplasma fermentans (M.F.), which belongs to the Mollicutes class, is a self-replicating wall-less prokaryote, surrounded only by a plasma membrane and with limited metabolic capabilities [21,22]. M.F. has been associated with the onset and progression of several human pathologies [23], including chronic inflammatory diseases such as rheumatoid arthritis [24,25], respiratory and genitourinary tract infections [26]. M.F. pathogenesis is through sophisticated mechanisms for evasion of immune surveillance (molecular mimicry and a unique type of antigenic variation), up-regulating or down-regulating cytokines secretion, adhesion molecules and transcription factors expression, and MAP kinases activity [22,27]. M.F. induces the production of cytokines such as IL-1, IL-2, IL-4, IL-6, interferons, TNF- $\alpha$ and GM-CSF [28]. Although the immunomodulatory role of M.F. is well established, its pathogenic mechanisms remain mostly unknown.

Monocyte Chemoattractant Protein-1 (MCP-1), also known as CCL2, is a member of the C-C chemokine family and a potent chemotactic factor for monocytes. MCP-1 is produced by a variety of cell types and monocyte/macrophages are the major source of this chemokine [29]. MCP-1 mediates its effects through its receptors CCR2 and CCR4 and regulates the migration and infiltration of monocytes, memory $\mathrm{T}$ lymphocytes and natural killer cells [30]. In addition to its chemotactic activity for leukocytes, several line of evidence indicate that MCP-1 plays a role in tumor metastasis and angiogenesis, as well as in the modulation of cell proliferation, apoptosis and protein synthesis [31]. Of note, MCP-1 is a potential intervention point for the treatment of various diseases, including multiple sclerosis [32], rheumatoid arthritis [33], atherosclerosis [34] and insulin-resistant diabetes [35].

Monocytes/macrophages play a central role in the initiation and resolution of inflammation: they act principally through phagocytosis, release of pro-inflammatory cytokines and reactive oxygen species (ROS) and the activation of the acquired immune system. M.F. triggers rapid recruitment of a large number of macrophages especially into the lungs and airways, thus monocytes/macrophages play critical role in M.F. clearance [36].

There is a growing interest in "medical gasses" for their antibacterial and anti-inflammatory properties. In this study we investigated the effects of $\mathrm{H}_{2} \mathrm{~S}$ in M.F. infection. Due to the relevance of monocytes/macrophages in inflammation and against M.F. infection [23,37], we used primary macrophages cultures and human monocytic cell line U937 as an in vitro model to investigate the effects of $\mathrm{H}_{2} \mathrm{~S}$ on the expression of MCP-1 pro-inflammatory chemokine following M.F. infection.

\section{Methods}

\section{Bacterial strains and culture conditions}

Mycoplasma fermentans (M.F.) PG18 (American Type Culture Collection) was grown in 243 media: heart infusion broth (BD) media supplemented with $20 \%$ heat inactivated horse serum and $10 \%$ yeast extract solution (Invitrogen, Grand Island, NY, USA), at $37^{\circ} \mathrm{C}$ in aerobic conditions. Mycoplasma cultures were harvested in late log phase and collected by centrifugation $(10 \mathrm{~min}$ at 10,000 $\times \mathrm{g}$ at $4^{\circ} \mathrm{C}$ ), and washed three times with PBS before using. Cells were infected with a concentration of 2 CFU/cell.

U937 cells were grown in RPMI 1640 Medium (Invitrogen, Grand Island, NY, USA) supplemented with 10\% fetal bovine serum (FBS).

Peripheral blood mononuclear cells (PBMC) were isolated by Ficoll-Hystopaque density-gradient centrifugation (Sigma-Aldrich, St. Louis, MO, USA) of heparinized leukocyte units obtained from healthy donors purchased from the New York Blood Center. To obtain primary macrophages cultures, PBMC were seeded into 24-well plates at $3 \times 10^{6}$ per well or 12 -well plates at $5.7 \times 10^{6}$ per well in RPMI 1640 medium (Invitrogen, Grand Island, NY, USA) supplemented with 20\% FBS (Gemini Bio-Products, Burlington, Ontario, Canada) and 10\% human serum 
(Gemini Bio-Products, Burlington, Ontario, Canada). Seven days later, when the macrophages monolayers were well established, the cultures were washed several times to remove non adherent cells, and then cultured in the medium described above but lacking human serum. Cultures were fed at 3 days intervals with a complete medium exchange.

\section{Cells treatments}

Cells were treated with NaHS at $1 \mathrm{mM}$ (Sigma-Aldrich, St. Louis, MO, USA) and GYY4137 at $100 \mu \mathrm{M}$ (Santa Cruz Biotechnology, Dallas, TX, USA) final concentration, and the related controls: $\mathrm{NaHCO}_{3}$ (Sigma-Aldrich, St. Louis, MO, USA) for NaHS and PBS (Invitrogen, Grand Island, NY, USA) for GYY4137. Reagents were added directly into the culture medium. Optimal and non-toxic NaHS and GYY4137 concentration were determined by treating U937 with $0.02,0.1,0.5,1$ or $2 \mathrm{mM} \mathrm{NaHS}$ and GYY4137 for 24 hours. NaHS and GYY4137 range of concentrations was chosen in reference to the physiological level of $\mathrm{H}_{2} \mathrm{~S}$ in the body. The cells viability was determined with propidium iodide (PI) $(2.5 \mu \mathrm{g} / \mathrm{ml})$ staining and analyzed by flow cytometry.

Cells were also treated with IKK Inhibitor VII (200 nM) and TIRAP Inhibitor peptide $(10 \mu \mathrm{M})$ to induce NF- $\mathrm{B}$ inhibition, MyD88 Inhibitory Peptide $(75 \mu \mathrm{M})$ to inhibit the homodimerization of MyD88, the major adaptor molecule for all TLRs, and SB203580 (400 $\mu \mathrm{M})$, an inhibitor of p38-MAP kinase. The correct concentrations were obtained by MTS assay (CellTiter 96 Aqueous One Solution Reagent - Promega). All inhibitors were from Calbiochem (EMD Millipore, Billerica, MA, USA) with the exception of MyD88 Inhibitory Peptide that was from Novus Biologicals (IMGENEX, San Diego, CA, USA). Equal volumes of DMSO or MyD88 control peptide were added to control samples. All inhibitors were added to the culture medium every $24 \mathrm{~h}$ at pre-determined optimal and nontoxic concentrations (data not shown).

\section{Cytokines assay}

Bio-Plex Pro $^{\text {тм }}$ human cytokine 27-plex immunoassay (BioRad, Hercules, CA, USA) was used to detect the following cytokines and chemokines: IL- $1 \beta$, IL-1 $\alpha$, IL-2, IL-4, IL-5, IL-6, IL-7, IL-8, IL-9, IL-10, IL-12, IL-13, IL-15, IL-17A, IL-18, Eotaxin, basic FGF, G-CSF, GM-CSF, IFN$\gamma$, IP-10, MCP-1, MIP-1 $\alpha$, MIP-1 $\beta$, RANTES, TNF- $\alpha$, PDGF, VEGF, CTACK, GRO $\alpha, \mathrm{HGF}$, IFN $\alpha 2$, MCP-3, MIF, MIG, SCF.

Quantikine ELISA Human CCL2/MCP1 Immunoassay (R\&D Systems Inc, Minneapolis, MN, USA) was then used to measure the MCP-1 production, and Luminex Performance Assay Human MMP-12 kit (R\&D Systems Inc, Minneapolis, MN, USA) to detect MMP-12.
ELISA assays were performed following the manufacturer's instructions.

\section{Cell Viability (Calcein) assay}

Calcein Assay was used to determine cells viability after infection and treatments and to normalize measurements from ELISA assays. 200ul of each sample was resuspended in medium without phenol red and dispensed in black 96-culture plate in triplicate. After washing, cells were incubated for 1 hour at $37^{\circ}$ in $4 \mu \mathrm{M}$ Calcein-AM solution (Sigma-Aldrich, St. Louis, MO, USA). Finally, fluorescence was measured at an excitation wavelength of $494 \mathrm{~nm}$ and an emission wavelength of $530 \mathrm{~nm}$, in a plate reader. The percentage of viable cells was calculated using the following formula:\% Live Cells $=\left[F(530)_{\text {sam }}-F(530)_{\text {min }}\right] \times 100 \%$, $F(530)_{\text {max }}$.

where $\mathrm{F}(530)_{\text {sam }}$ is the fluorescence at $530 \mathrm{~nm}$ in the experimental cell sample labeled with Calcein AM; F $(530)_{\min }$ is the fluorescence at $530 \mathrm{~nm}$ in a sample not labeled with Calcein AM (cell auto-fluorescence) and F $(530)_{\max }$ is the fluorescence at $530 \mathrm{~nm}$ in a sample where all or nearly all cells are alive, labeled with Calcein AM (sample control).

\section{NF-KB transcription factor assay}

The activation of transcription factor NF-kB in U937 cells was determined using the NF- $\mathrm{B}$ family-Transcription Factor Assay Kit (Active Motif, Carlsbad, CA, USA). Cells were plated at a concentration of $9 \times 10^{6}$ cells and were harvested $18 \mathrm{~h}$ after M.F. infection and $\mathrm{H}_{2} \mathrm{~S}$ treatment. Cytoplasmic and nuclear cell fractions were prepared using the Nuclear Extract Kit (Active Motif, Carlsbad, CA, USA) according to the manufacturer's instructions. Protein concentration was determined using Bradford protein assay method and equal amounts of protein extracts (20 $\mu \mathrm{g}$ for p52 and p65, $40 \mu \mathrm{g}$ for p50) were analyzed. The activated NF- $\mathrm{kB}$ subunits were detected at $450 \mathrm{~nm}$ with a plate reader after treatment with primary antibodies directed against either NF- $\mathrm{kB}$ p65, p50 or p52 subunits and followed by a secondary antibody conjugated to horseradish peroxidase (HRP), according to the manufacturer's instructions.

\section{Real time quantitative RT-PCR (qRT-PCR)}

U937 cells plated at a concentration of $1 \times 10^{6}$ cells/well in 6 well-plates and macrophages plated in 12well-plates were used to perform the real time PCR. Cells were infected with M.F. and treated with the established concentrations of sulfide donors and then collected at 3 hours, 6 hours, 18 hours and 24 hours after the infection/treatments. RNA was extracted with the RNeasy Mini Kit (Qiagen, Frederick, MD, USA). $2 \mu \mathrm{g}$ of RNA were reverse transcribed (iScript cDNA Synthesis Kit, BioRad, Hercules, CA, USA) and then subjected to real 
time PCR using the iQ SYBR Green Supermix (BioRad, Hercules, CA, USA). The cDNAs were amplified with specific primers for MCP-1 (forward, 5'-CATAGCAG CCACCTTCATTCC-3', reverse 5'-TCTCCTTGGCCA CAATGGTC-3'). Glyceraldehyde 3-phosphate dehydrogenase, GAPDH (forward, 5'-CCATGGAGAAGGCTGGG G-3', reverse 5'-CAAAGTTGTCATGGATGACC-3') was used as the housekeeping gene control. cDNAs were also amplified with specific primers for MMP-12 (forward, 5'TGCACATTTCGATGAGGACG-3', reverse 5'-GGGAC TGAATGCCACGTATG-3'). Primers were selected using the NCBI/primer-blast program (www.ncbi.nlm.nih.gov/ tools/primer-blast/) and were synthesized by Sigma-Aldrich (Sigma-Aldrich, St. Louis, MO, USA). Amplification (30 sec of denaturation at $95^{\circ} \mathrm{C}, 35 \mathrm{sec}$ of annealing at $65^{\circ} \mathrm{C}$ and $30 \mathrm{sec}$ of extension at $72^{\circ} \mathrm{C}$ ) was performed for 35 cycles with MCP-1 and MMP-12 primers. For GAPDH primers, PCR was performed with the following protocol: 28 cycles of $30 \mathrm{sec}$ at $94^{\circ} \mathrm{C}, 35 \mathrm{sec}$ at $60^{\circ} \mathrm{C}$ and $30 \mathrm{sec}$ at $72^{\circ} \mathrm{C}$.

All reactions were run in triplicate. Semi-quantitative analysis was based on the cycle number $\left(C_{T}\right)$ at which the SYBR Green fluorescent signal crossed a threshold in the log-linear range of RT-PCR. The fold change in MCP-1 RNA in U937 and in infected macrophages was compared with the uninfected control at time zero of the experiment and is shown relative to the change in the expression of GAPDH RNA that was measured as an internal control.

\section{Results}

Mycoplasma infection induces MCP-1 in U937 cells and in human monocyte-derived macrophages

The induction of pro-inflammatory cytokines is a hallmark of M.F.-mediated inflammatory activity [22]. When we measured the production of cytokines and chemokines in M.F. infected cells we observed a marked increase in cytokines and chemokines production, such as MCP-1, IL-8 and IFN $\gamma$ [38]. According to these results and to the role played by MCP-1 in inflammation [39], we focused our studies on this chemokine. Indeed, MCP-1 is secreted by several cells types, especially monocytes, and is responsible for the direct migration of the cells toward the endothelium at the sites of inflammation and lesion formation [30].

In order to verify MCP-1 induction, macrophages and U937 cells were infected with M.F. Culture supernatants were collected at day 1, 2 and 3 following the infection and the chemokines production was measured. Uninfected cells, treated with 243 M.F. growth media (v/V), were used as controls. While basal levels of MCP-1 were produced by U937 monocytic cell line (about $40 \mathrm{ng} / \mathrm{ml}$ ) [Figure 1A], infection with M.F. induced an increase in $\mathrm{MCP}-1$ production with a peak 6-fold increase at 48 hours.
In agreement with the ELISA data, we also observed an increase of MCP-1 mRNA both in 243 treated and M.F. infected cells, however at 24 hours the MCP-1 mRNA level in M.F. infected cells was significantly greater compared with the control (31.7-fold increase in M.F. infected cells versus 19.1-fold increase in the control) [Figure 1B].

A similar effect was observed when macrophages were infected with M.F. We observed a gradual increase in MCP-1 production with peak levels at 72 hours following M.F. infection. The increase in MCP-1 production was 5.7-fold higher compared to the control [Figure $1 \mathrm{C}$ ].

MCP-1 mRNA induction following M.F. infection in macrophages was also increased at 18 hours [Figure 1D] with a 112.75 -fold increase versus 0.41 -fold increase in the control macrophages treated with 243 M.F. growth media.

These results suggest that M.F. induces MCP-1 expression and secretion both in U937 cells and in macrophages.

Mycoplasma infection induces Matrix Metalloproteinase-12 (MMP-12) in U937 cells and in human monocyte-derived macrophages

MCP-1 is produced as an inactive poly-protein and requires processing by MMP-12 (Matrix Metalloproteinase-12) to become functionally active [40]. Therefore we tested MMP-12 expression in U937 and macrophages infected with M.F. We measured MMP-12 levels by ELISA and we observed a marked increase of the enzyme after 48 hours $(340 \mathrm{ng} / \mathrm{ml})$ [Figure 2A]. Accordingly, U937 cells produced MMP-12 mRNA with a 16.8-fold peak of mRNA after 18 hours of culture. However, M.F. infection increased MMP-12 mRNA by 41.2-fold at 18 hours and 46fold at 24 hours [Figure 2B].

Similar to U937, macrophages showed an increase in MMP-12 secretion with a peak at 72 hours following M.F. infection (about $27 \mathrm{ng} / \mathrm{ml}$ ), compared to control (about $0.76 \mathrm{ng} / \mathrm{ml}$ measured in untreated control and $0.9 \mathrm{ng} / \mathrm{ml}$ 243 media treated) [Figure 2C].

Moreover, MMP-12 mRNA was increased in M.F. infected macrophages with a 6.3-fold peak after 18 hours of infection, versus 0.59 -fold increase in the corresponding control. At 24 hours of culture, M.F.-infected cells had increased MMP-12 mRNA expression of 4.95-fold versus 1.04-fold in the control [Figure 2D].

Taken together these results show that MCP-1 and its activating factor MMP-12 are produced from U937 cells and macrophages infected with M.F, suggesting that MCP-1 is functionally active.

Sulfur compounds inhibit MCP-1 production in U937 cells and in human monocyte-derived macrophages

In order to test the anti-inflammatory effect of $\mathrm{H}_{2} \mathrm{~S}$ in M.F.-infected cells we used two different $\mathrm{H}_{2} \mathrm{~S}$ donors: the fast-releasing $\mathrm{H}_{2} \mathrm{~S}$ donor sodium hydrosulfide 
A

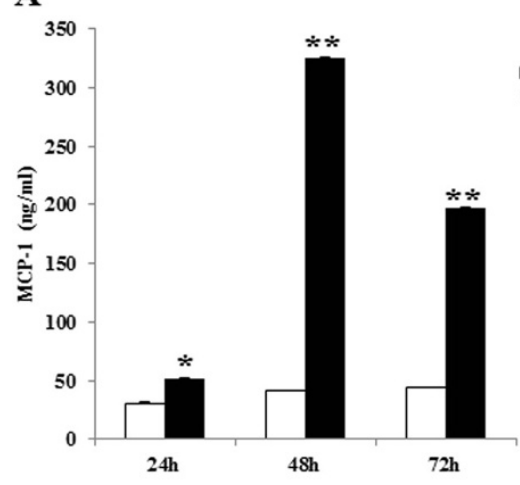

C

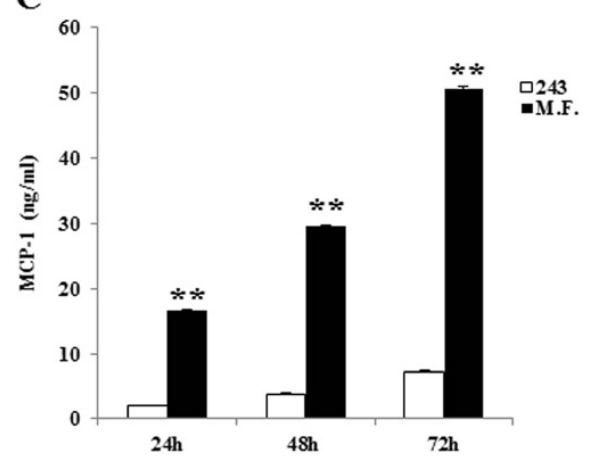

B

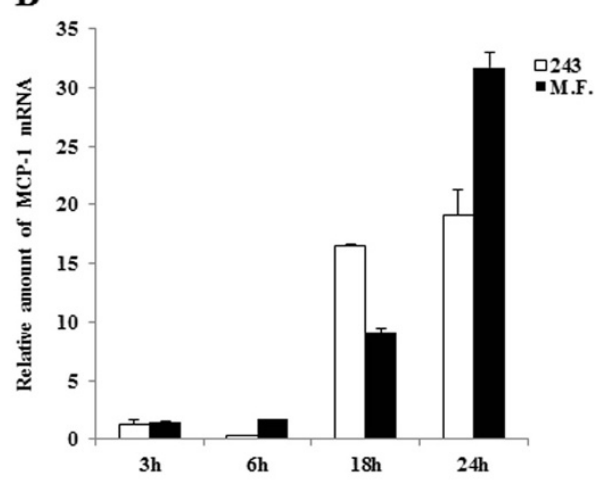

D

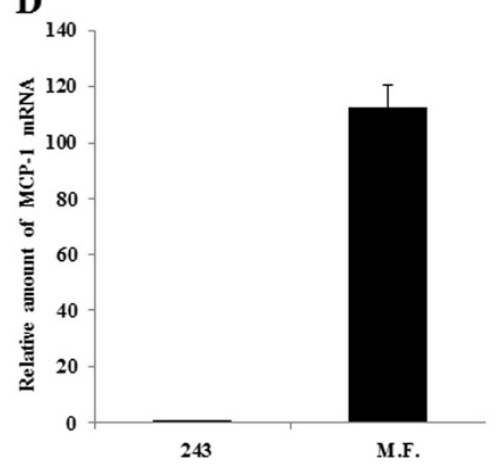

Figure 1 MCP-1 induction by M.F. in U937 cells and macrophages. A: U937 cells were infected with M.F. and the supernatants were collected at the following time points 24 h, 48 h, 72 h, and tested for MCP-1 production by ELISA. Levels of MCP-1 were indicated at each time point. B: RNA samples from U937 cells infected with M.F. were collected at the established time points ( $3 \mathrm{~h}, 6 \mathrm{~h}, 18 \mathrm{~h}$ and $24 \mathrm{~h}$ ). MCP-1 expression was analyzed by real time quantitative RT-PCR as described in Materials and methods procedures. U937 cells treated with 243 M.F. growth media (VN) were used as controls for both analysis (ELISA and qRT-PCR). C: Macrophages were infected with M.F. and the supernatants were tested for MCP-1 production by ELISA assay. The supernatants were collected at $24 \mathrm{~h}, 48 \mathrm{~h}$ and $72 \mathrm{~h}$ following infection. Levels of MCP-1 were indicated at each time point in M.F. infected samples and in the respective controls (uninfected cells and cells treated with 243 M.F. medium). D: MCP-1 expression was analyzed by real time RT-PCR in RNA samples from macrophages infected with M.F. MCP-1 relative amount of mRNA at $18 \mathrm{~h}$ following the infection is shown. Macrophages treated with 243 M.F. growth media (VN) were used as controls. MCP-1 production (ELISA) was normalized with the calcein viability assay, as described in the Materials and Methods, in both experiments. Bars denote the standard deviation. The $p$-values were calculated as unequal variance t-test of Mycoplasma infected cells relative to 243 media control: * $p \leq 0.05$; ${ }^{* *} p \leq 0.005$. The histograms shown are representative of data from three different experiments.

(NaHS) and the morpholin-4-ium-4-methoxyphenyl(morpholino)-phosphinodithioate (GYY4137), a novel water-soluble molecule that, unlike NaHS, decomposes slowly to generate small amounts of $\mathrm{H}_{2} \mathrm{~S}$ both in vitro and in vivo [41].

NaHS and GYY4137 were directly added to the culture medium at optimal and non-toxic concentrations (see Methods) at the time of M.F infection.

As expected, M.F. infection induced an increase in MCP-1 production, which was most remarkable after 48 hours of infection in U937 cells $(\mathrm{p}=0.01)$ [Figure 3A] and after 72 hours of infection in macrophages $(\mathrm{p}=0.04)$ [Figure 3B].

Both NaHS and GYY4137 reduced MCP-1 production [Figure 3]. When U937 were infected, the effect was more marked with GYY4137 treatment compared to $\mathrm{NaHS}$ treatments both at 48 hours [2.1-fold reduction of
MCP-1 following GYY4137 treatments ( $\mathrm{p}=0.012)$, versus 1.7-fold reduction of MCP-1 following NaHS treatments $(p=0.018)$ ] and 72 hours [1.9-fold reduction of MCP-1 following GYY4137 treatments $(\mathrm{p}=0.006)$, versus 1.6fold reduction following NaHS treatments $(p=0.012)$ ] [Figure 3A]. No changes in MCP-1 production were observed with the respective control treatments (data not shown).

A similar effect was also observed when monocytes/macrophages were infected with M.F. However the amount of cytokines induced was lower compared to U937 cells, suggesting that MCP-1 production may be donor-dependent. MCP-1 was induced following M.F. infection and treatments with both NaHS and GYY4137 reduced cytokine production. Unlike U937 cells, the inhibitory effects of NaHS was more marked compared to GYY4137 treatments, both at 48 hours [1.4-fold reduction of MCP-1 

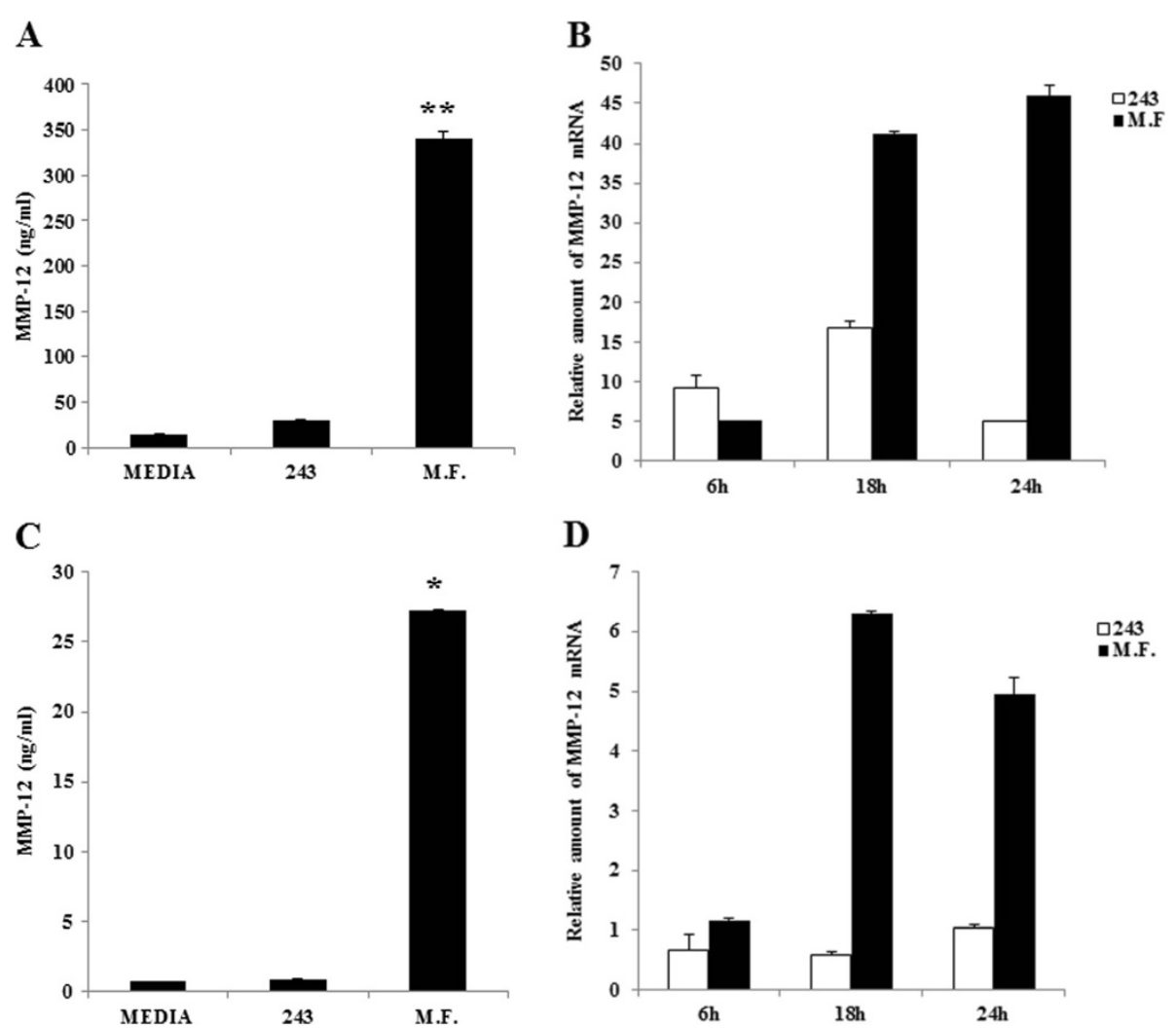

D

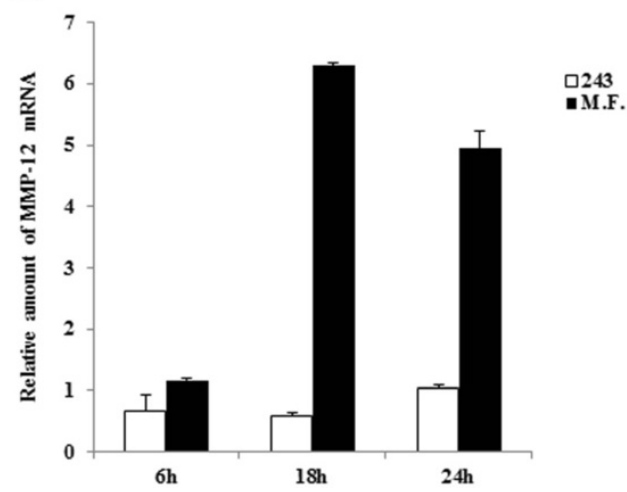

Figure 2 Induction of MMP-12 mRNA and protein by M.F. in U937 cells and in macrophages. M.F.-infected cells were analyzed by ELISA and real time PCR to detect the M.F. effects on MMP-12. A: $48 \mathrm{~h}$ following the infection, the U937 supernatants were collected and analyzed with the ELISA assay. U937 treated with 243 M.F. growth media ( $V$ N) were used as controls for both analysis (ELISA and qRT-PCR). B: RNA samples from U937 cells were collected at the established time points ( 6 h, $18 \mathrm{~h}$ and $24 \mathrm{~h}$ ) following M.F. infection. MMP-12 expression was analyzed by real time qRT-PCR as described in Materials and Methods. C: Macrophage culture supernatants were harvested $48 \mathrm{~h}$ the M.F. infection and tested by ELISA. Uninfected cells and 243 media treated cells were used as controls. D: RNA samples from M.F.-infected macrophages were collected at the following time points: 6 h, 18 h and 24 h. MCP-1 expression was analyzed by real time RT-PCR. Macrophages treated with 243 M.F. growth media ( $V N$ ) were used as controls. In both ELISA tests, MCP-1 production was normalized with the Calcein viability assay, as described in the Materials and Methods. Bars denote the standard deviation. The $\mathrm{p}$-values were calculated as unequal variance t-test of Mycoplasma infected cells relative to 243 media control: ${ }^{*} p \leq 0.05 ;{ }^{* *} p \leq 0.005$. The histograms shown are representative of data from three different experiments.

following GYY4137 treatments ( $\mathrm{p}=0.012)$, versus 16.1-fold reduction of MCP-1 following NaHS treatments $(\mathrm{p} \leq$ $0.001)]$ and 72 hours [1.44-fold reduction of MCP-1 following GYY4137 treatments $(\mathrm{p}=0.02)$, versus 16.55 -fold reduction following NaHS treatments $(\mathrm{p} \leq 0.001)]$. No changes in MCP-1 production were observed with the respective control treatments [Figure 3B].

These results highlight the anti-inflammatory effect of $\mathrm{H}_{2} \mathrm{~S}$ in M.F.-infected cells.

We then asked the question if the time of $\mathrm{H}_{2} \mathrm{~S}$ treatment relative to M.F. infection could affect MCP-1 production. We designed the experiments by pretreating cells with $\mathrm{H}_{2} \mathrm{~S}$ at $24 \mathrm{~h}, 6 \mathrm{~h}, 1 \mathrm{~h}$ before M.F. infection, contemporary to M.F. infection or $1 \mathrm{~h}, 6 \mathrm{~h}$ and $24 \mathrm{~h}$ following the infection. The supernatants were collected $48 \mathrm{~h}$ and $72 \mathrm{~h}$ following the infection and MCP-1 production was measured. Our data show that $1 \mathrm{~h}$ or $6 \mathrm{~h}$ of $\mathrm{H}_{2} \mathrm{~S}$ treatment before or after M.F. infection does not affect the amount of MCP-1 production, and are comparable to $\mathrm{MCP}-1$ produced when $\mathrm{H}_{2} \mathrm{~S}$ treatment was contemporary to M.F. infection. In contrast, when U937 cells were pre-treated with $\mathrm{H}_{2} \mathrm{~S} 24 \mathrm{~h}$ before M.F. infection, the amount of MCP-1 produced was lower compared to the contemporary treatments [2.13-fold reduction of MCP-1 following NaHS treatments $(p=0.04)$ and 9.42-fold reduction of MCP-1 following GYY4137 treatments $(\mathrm{p} \leq 0.001)$ ], suggesting that early treatments with $\mathrm{H}_{2} \mathrm{~S}$, and in particular with GYY4137, markedly reduce inflammation caused by M.F. [Figure 4].

Finally, when U937 cells were treated $24 \mathrm{~h}$ post infection there was an increase in MCP-1 production at $48 \mathrm{~h}$ [1.23-fold reduction of MCP-1 following NaHS treatments $(\mathrm{p}=\mathrm{ns})$ and 2.35-fold reduction following GYY4137 treatments $(p=0.001)$ ], suggesting that at this time point the protective effect of $\mathrm{H}_{2} \mathrm{~S}$ is reduced. 

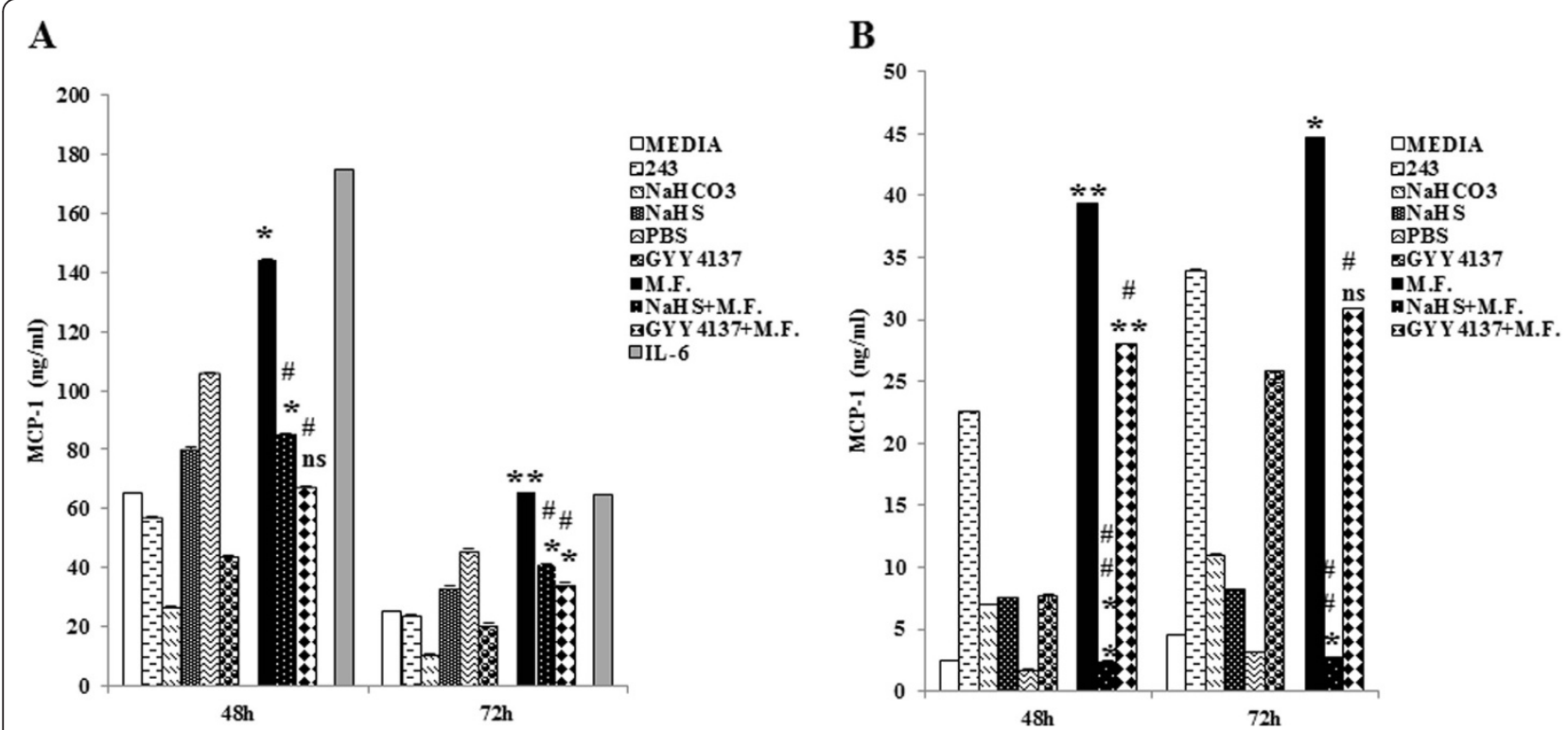

Figure 3 Inhibition of MCP1 production by $\mathrm{H}_{2} \mathrm{~S}$ in M.F. infected U937 cells and macrophages. A: U937 cells were infected with M.F., the two $\mathrm{H}_{2} \mathrm{~S}$ donors (NaHS and GYY4137) were directly added to the media at the concentrations of $1 \mathrm{mM}$ for NaHS and $0.1 \mathrm{mM}$ for GYY4137 and the supernatants were collected $48 \mathrm{~h}$ and $72 \mathrm{~h}$ after the infection/treatments, and tested for MCP-1 production by ELISA. IL-6 was used as positive control for MCP-1 production. B: Macrophages were infected by M.F. and treated with $\mathrm{H}_{2} \mathrm{~S}$ donors at the same concentrations (1 mM for NaHS and $0.1 \mathrm{mM}$ for GYY4137) and the supernatants were tested by ELISA assay at $48 \mathrm{~h}$ and $72 \mathrm{~h}$ following infection and $\mathrm{H}_{2} \mathrm{~S}$ treatments. MCP-1 production was normalized with the Calcein viability assay, as described in the Materials and Methods, in both experiments. Bars denote the standard deviation. The $p$-values were calculated as unequal variance t-test of Mycoplasma infected cells relative to 243 media control $\left({ }^{*} p \leq 0.05\right.$; ${ }^{* *} \mathrm{p} \leq 0.005$; ns not significant) and as unequal variance t-test of Mycoplasma infected cells treated with $\mathrm{H}_{2} \mathrm{~S}$ donors relative to Mycoplasma infected cells (\#p $\leq 0.05$; \#\#p $\leq 0.005)$. The histograms shown are representative of data from five different experiments.

Mycoplasma induces MCP-1 with a TLR-mediated mechanism Different signal pathways including NF- $\mathrm{KB}$ [42], and MAP kinases ERK1/2 and p38 [43] have been implicated in MCP-1 induction. In accordance to that, mycoplasmal lipopeptides are known to activate the NF- $\mathrm{B}$ pathway [44] with a TLR-mediated mechanism, inducing proinflammatory cytokines.

In order to define the signal pathway/s mediating M.F. induced MCP-1 production, we treated M.F.-infected cells with specific inhibitors, precisely TIRAP inhibitor peptide, IKK Inhibitor VII (IKK and IKB $\alpha$ inhibitors), MyD88 Inhibitory Peptide (MyD88 homodimerization inhibitor) and SB203580 (p38 MAP kinase inhibitor). Inhibitors were added directly to the cultures $1 \mathrm{~h}$ before infection (see Methods). Supernatants were collected $48 \mathrm{~h}$ and $72 \mathrm{~h}$ following M.F. infection and analyzed. Our results show that the specific inhibitors TIRAP and IKK Inhibitor VII [Figure $5 \mathrm{~A}$ ] were able to reduce $\mathrm{MCP}-1$ production by 3.46 -fold ( $\mathrm{p} \leq 0.001)$ and 2.57 -fold $(\mathrm{p} \leq 0.001)$ respectively. A more potent effect was observed after inhibiting MyD88 homodimerization, with a 6.57-fold reduction in MCP-1 production $(\mathrm{p}=0.03)$ [Figure $5 \mathrm{~B}$ ]. No effect was observed with SB203580, suggesting that p38 MAPK pathway is not involved in MCP-1 induction following M.F. infection [Figure 5A]. These data suggest that M.F. induces MCP-1 expression through a TLR (toll like receptor)-NF- $\mathrm{kB}$ pathway.
Sulfur compounds block MCP-1 production by inhibiting NF-KB activation

In order to determine if $\mathrm{H}_{2} \mathrm{~S}$ plays a role in NF- $\mathrm{KB}$ signaling, we analyzed cytoplasmic and nuclear NF- $\mathrm{kB}$ subunits (p65, p50, p52) during M.F. infection, with or without $\mathrm{H}_{2} \mathrm{~S}$ [Figure 6]. We expressed the nuclear subunit as a percentages calculated over the total of NF- $\mathrm{KB}$ subunits (nuclear and cytoplasmic), that was detected as Absorbance (OD) reading at $450 \mathrm{~nm}$.

M.F. infection caused an increase of p65 (74.1 $\pm 12.13 \%$ in M.F.-infected cells versus $45.5 \%$ in the control) $(\mathrm{p}=0.01)$ and p50 subunits $(57.9 \pm 2.24 \%$ in M.F.-infected cells versus $51.7 \%$ in the control) $(\mathrm{p}=0.02)$ in the NF- $\mathrm{kB}$ nuclear fraction, while no change was observed for the p52 subunit $(p=0.004)$. Treatment of the M.F.-infected cultures with $\mathrm{H}_{2} \mathrm{~S}$ had a protective effect, particularly with the slow releasing donor GYY4137. Indeed, treatment of infected cells with GYY4137 caused a 10\% reduction in the nuclear p50 subunit $(\mathrm{p}=0.019)$, while NaHS had no effects. $\mathrm{H}_{2} \mathrm{~S}$ had a more potent effect in reducing the amount of nuclear p65 subunit in infected cells: while NaHS caused $11 \%$ of reduction in nuclear p65 ( $\mathrm{p}=0.05)$, GYY4137 completely abrogated the increase in nuclear p65 caused by M.F. infection $(45.6 \pm 1.41$ versus 51.7 in the control) $(\mathrm{p}=0.009)$.

These results suggest that $\mathrm{H}_{2} \mathrm{~S}$ interfere with the activation and nuclear translocation of p52 and p65 subunits, 


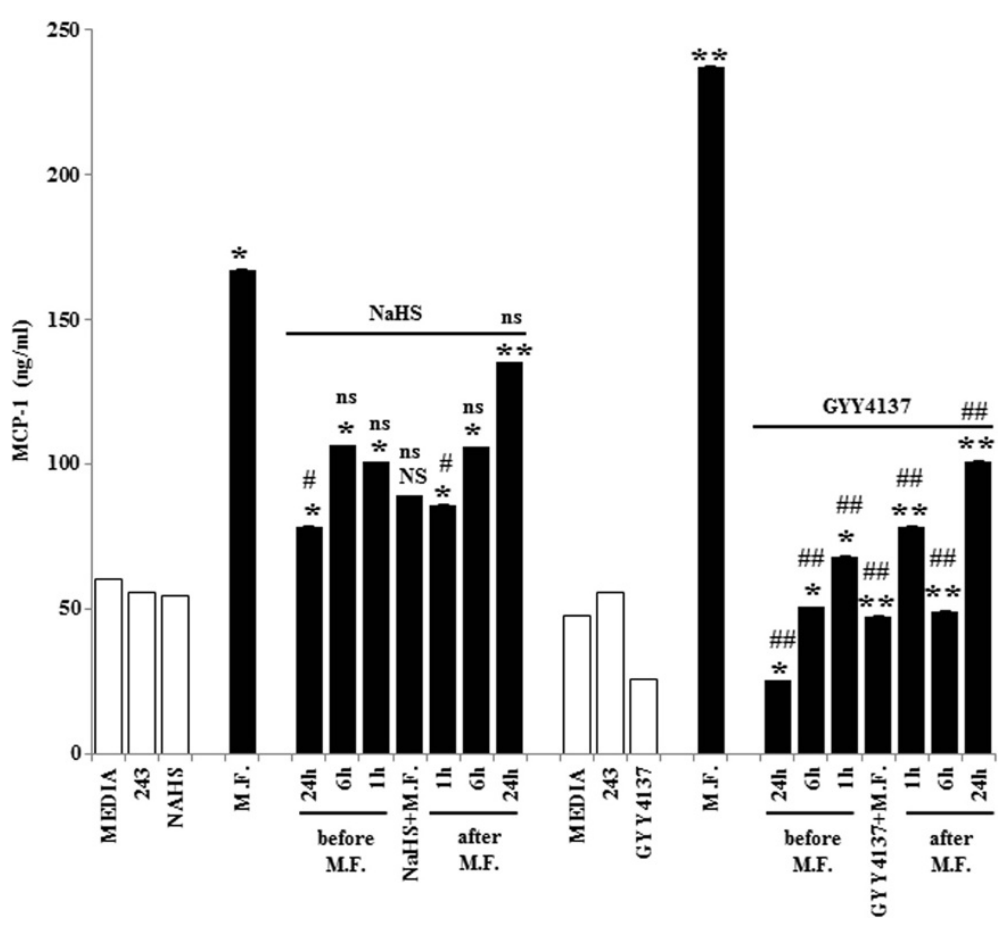

Figure 4 Inhibition of MCP-1 production by $\mathrm{H}_{2} \mathrm{~S}$ is time-dependent. U937 cells were infected and treated with NaHS and GYY4137 in the following ways: at the time of M.F. infection, 1 h, 6 h, 24 h before the infection or 1 h, 6 h, $24 \mathrm{~h}$ after the infection. The supernatants were collected $48 \mathrm{~h}$ and $72 \mathrm{~h}$ following the infection and MCP-1 production was measured by ELISA. The chemokine production was normalized with the Calcein viability assay. $48 \mathrm{~h}$ time point is presented here. Bars denote the standard deviation. The p-values were calculated as unequal variance t-test of Mycoplasma infected cells relative to 243 media control $\left({ }^{*} p \leq 0.05 ;{ }^{* *} p \leq 0.005\right.$; NS not significant) and as unequal variance t-test of Mycoplasma infected cells treated with $\mathrm{H}_{2} \mathrm{~S}$ donors relative to Mycoplasma infected cells (\#p $\leq 0.05$; \#\# $\leq 0.005$; ns not significant). The histograms shown are representative of data from three different experiments.

thus preventing NF-kB dimer binding to the promoters of a variety of pro-inflammatory genes.

\section{Discussion}

There is increasing evidence showing $\mathrm{H}_{2} \mathrm{~S}$ as a gaseous signaling molecule with a variety of effects on multiple systems. The protective effects of $\mathrm{H}_{2} \mathrm{~S}$, especially in the cardiovascular and in the nervous systems, are being increasingly explored. Several recent reports provide evidence suggesting a role for $\mathrm{H}_{2} \mathrm{~S}$ in inflammation [11].

Our work highlights the anti-inflammatory effects of $\mathrm{H}_{2} \mathrm{~S}$ during bacterial infection of macrophages with M.F.

M.F. is associated with several chronic inflammatory diseases, in particular with arthritis [24] and it has been also proposed as a putative co-factor in AIDS disease progression [45]. Multiple factors account to M.F. pathogenicity [46] and M.F. lipoproteins are known to cause innate immune response. Twenty one lipoproteins have been recently identified in the proteomics profile of MF64 [47] and among these, MALP-2 and M161 lipoproteins cause host immune activation through TLR. M161 also binds complement receptor inducing phagocytosis in macrophages and dendritic cells [23].
In our experiments, primary macrophage cultures and U937 monocytoid cell line were infected with M.F., inducing the production of pro-inflammatory cytokines; in particular MCP-1 was induced both at RNA and protein levels. The amount of MCP-1 induced in U937 cell lines (325.4 $\mathrm{ng} / \mathrm{ml}$ ) was constantly higher compared to the amount of MCP-1 induced in monocytes/macrophages $(50.7 \mathrm{ng} / \mathrm{ml})$ and was comparable to the MCP-1 plasma levels detected in human sepsis $(2.00-128.00 \mathrm{ng} / \mathrm{ml})$. It is known in fact that MCP-l plasma levels are detectable and increased in human sepsis and septic shock with respect to healthy patients: both surviving and nonsurviving patients with sepsis or septic shock showed increased MCP-1 plasma levels compared with those of controls $(<2.00 \mathrm{ng} / \mathrm{ml})$ [48].

M.F. also induced MMP-12 that, in addition to be a pro-inflammatory molecule, is required for processing MCP-1 in its active form, suggesting that M.F.-induced MCP-1 in our systems was functionally active.

Two different $\mathrm{H}_{2} \mathrm{~S}$ donors NaHS and GYY4137 were used to test the anti-inflammatory effects of $\mathrm{H}_{2} \mathrm{~S}$ in M.F. infected cells. Both $\mathrm{H}_{2} \mathrm{~S}$ donors showed anti-inflammatory activity by reducing MCP-1 production in M.F. infected cells. 

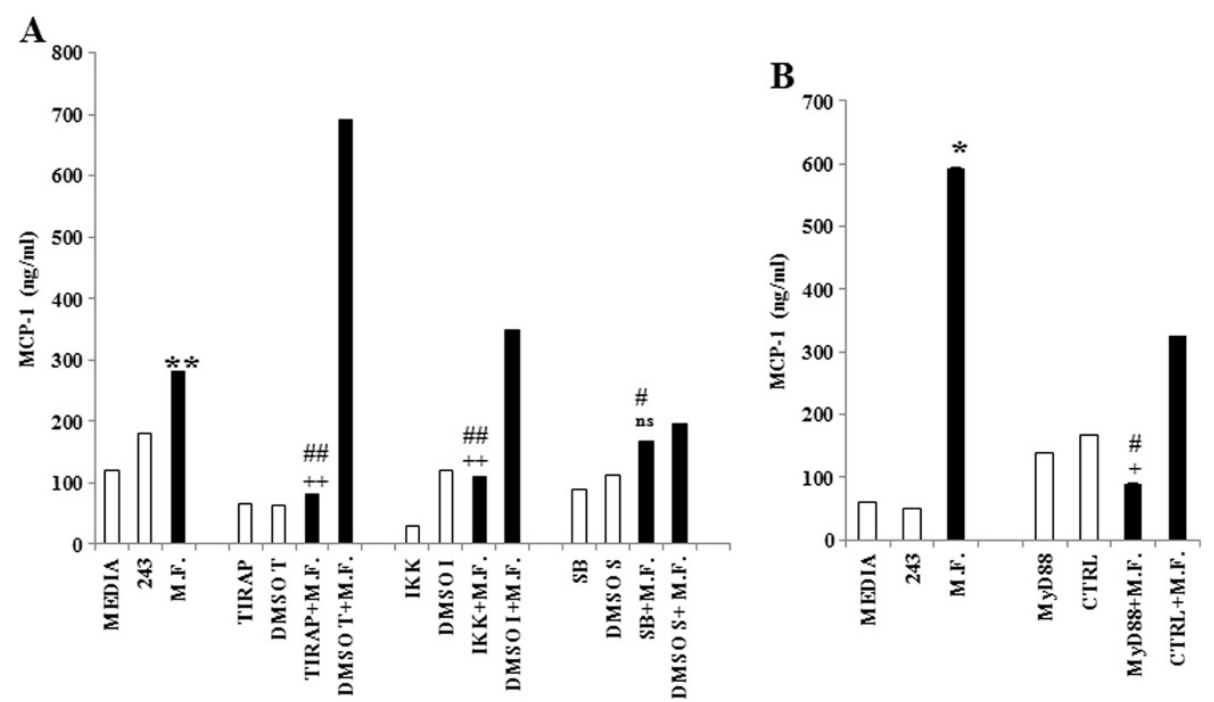

Figure 5 M.F. induction of MCP-1 through a TLR-mediated mechanism. U937 cells were infected with M.F. and treated with the following

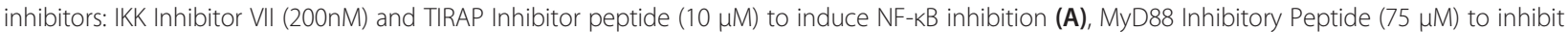
MyD88 homodimerization (B) and SB203580 (400 $\mu$ M) to inhibit p38-MAP (A). The inhibitors were added daily. Supernatants were collected at 48 hours and tested for MCP-1 production by ELISA assay. MCP-1 production was normalized with the Calcein viability assay, as described in the Materials and Methods section. Bars denote the standard deviation. The p-values were calculated as unequal variance t-test of Mycoplasma infected cells relative to 243 media control $\left({ }^{*} \mathrm{p} \leq 0.05 ;{ }^{* *} \mathrm{p} \leq 0.005\right)$, as unequal variance t-test of Mycoplasma infected cells treated with $\mathrm{H}_{2} \mathrm{~S}$ donors relative to Mycoplasma infected cells (\#p $\leq 0.05$; \#\# $\leq 0.005)$ and as unequal variance t-test of Mycoplasma infected cells treated with inhibitors relative to Mycoplasma infected cells treated with control inhibitors ( $+p \leq 0.05 ;++p \leq 0.005$; ns not significant). The histograms shown are representative of data from four different experiments.

However while GYY4137 anti-inflammatory effect was more potent in U937 cells, NaHS was more effective in macrophages. $\mathrm{H}_{2} \mathrm{~S}$ thus may represent a novel therapeutic molecule capable of limiting M.F.-induced inflammation, since it influences the levels of key chemokines like MCP-1 involved in the inflammatory process. Furthermore our results show that pre-treatment with $\mathrm{H}_{2} \mathrm{~S}$ could more efficiently impact the resolution of inflammatory process.

Treatment of M.F.-infected macrophages with pharmacological inhibitors demonstrated that M.F. induces MCP-1
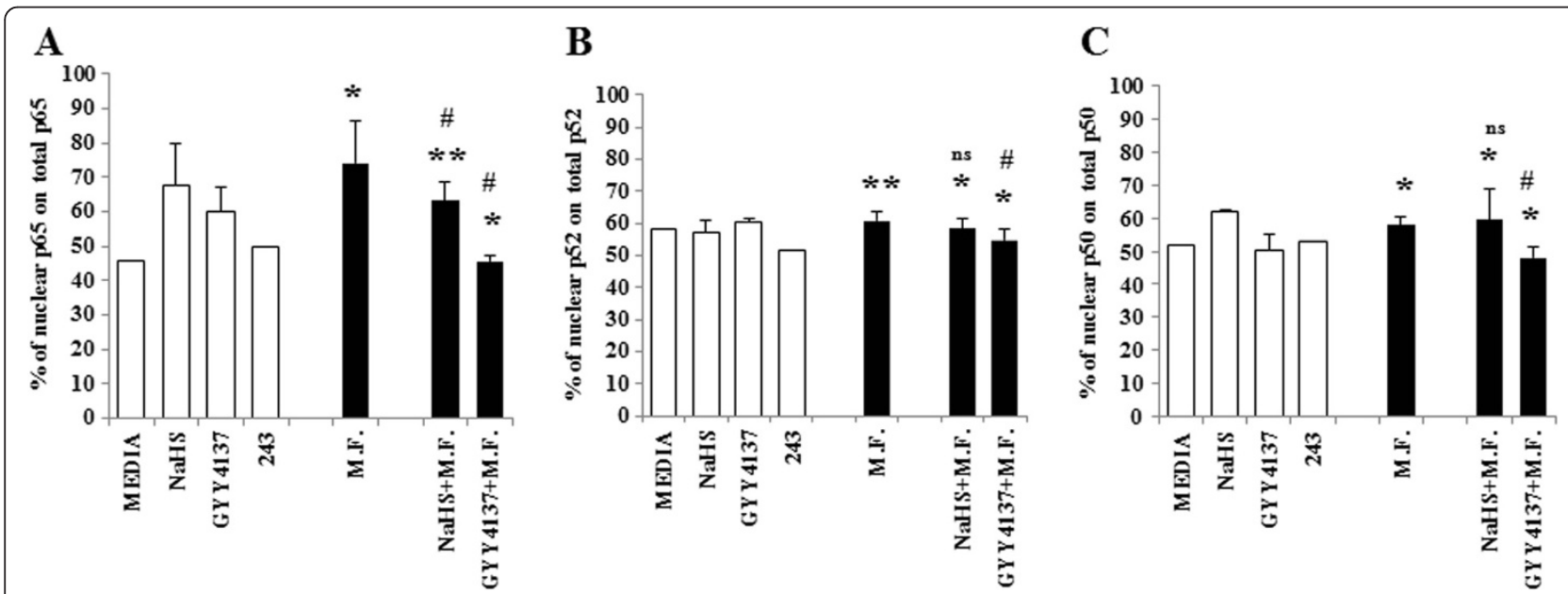

Figure 6 Inhibition of NF-KB activation by $\mathrm{H}_{2} \mathrm{~S}$ in M.F. infected U937 cells. U937 cells were pre-treated with the two $\mathrm{H}_{2} \mathrm{~S}$ donors NaHS $(1 \mathrm{mM})$ and GYY4137 (0.1 mM) for $24 \mathrm{~h}$. The cells were then infected with M.F. $18 \mathrm{~h}$ following infection the cells were collected and the cytoplasmic fraction was separated from the nuclear fraction. The percentages of NF-kB nuclear subunits p65 (A), p52 (B) and p50 (C) were calculated over the total of NF-KB subunits (nuclear and cytoplasmic) detected as Absorbance (OD) reading at $450 \mathrm{~nm}$. Bars denote the standard deviation. The $\mathrm{p}$-values were calculated as unequal variance t-test of Mycoplasma infected cells relative to 243 media control $\left({ }^{*} p \leq 0.05 ;{ }^{* *} p \leq 0.005\right)$ and as unequal variance t-test of Mycoplasma infected cells treated with $\mathrm{H}_{2} \mathrm{~S}$ donors relative to Mycoplasma infected cells (\#p $\leq 0.05$; \#\# $\leq 0.005$; ns not significant). The histograms shown are representative of data from three different experiments. 
expression through TLR-NF- $\mathrm{kB}$ pathway. In particular TIRAP and MyD88 inhibitor peptides were able to completely block MCP-1 production in M.F.-infected macrophages. This pathway is essential for the activation of most pro-inflammatory genes and the constitutive activation of NF- $\mathrm{kB}$ pathway is associated with inflammatory diseases such as rheumatoid arthritis, bowel disease, multiple sclerosis and asthma [49].

NF- $\mathrm{kB}$ subunits exist in the cytoplasm in inactive forms, as a result of their association with the IkB proteins [50]. In response to a wide range of stimuli, including pathogens, stress signals and pro-inflammatory cytokines, NF$\mathrm{KB}$ subunits are rapidly activated and translocated to the nucleus, assembled as NF- $\mathrm{kB}$ dimers which then induce the transcription of pro-inflammatory cytokines, chemokines, adhesion molecules, matrix metalloproteinases, cyclooxygenase 2 (COX2) and inducible nitric oxide synthase (iNOS) [51]. In agreement with our results obtained with the pharmacological inhibitors, M.F. infection of U937 caused nuclear translocation of p65 and p50 subunits, suggesting that M.F. infection activates the canonical NF-kB pathway. In contrast, treatment with $\mathrm{H}_{2} \mathrm{~S}$, particularly GYY4137, completely blocked the nuclear translocation of NF- $\mathrm{kB}$ heterodimer p65/p50. However NaHS only had a slight effect on NF-kB inhibition suggesting that this $\mathrm{H}_{2} \mathrm{~S}$ fast donor might use a different mechanism to inhibit bacterial inflammation.

Our findings that $\mathrm{H}_{2} \mathrm{~S}$ inhibits NF- $\mathrm{kB}$ nuclear accumulation indicate that $\mathrm{H}_{2} \mathrm{~S}$ may target directly TLR or any of the TLR adaptors proteins, as well as signaling proteins involved in NF- $\mathrm{KB}$ activation. Further studies are needed to see whether a specific component of the TLRNF- $\mathrm{KB}$ pathway is directly inhibited by $\mathrm{H}_{2} \mathrm{~S}$. Besides it is important to establish the mechanism of $\mathrm{H}_{2} \mathrm{~S}$ inhibition of TLR-NF- $\mathrm{KB}$ pathway. A recent study showed that $\mathrm{S}$-sulfhydration of NF- $\mathrm{kB}$ by $\mathrm{H}_{2} \mathrm{~S}$ is responsible for its anti-apoptotic actions [52], therefore it will be important to verify how $\mathrm{H}_{2} \mathrm{~S}$-mediated protein $\mathrm{S}$-sulfhydration affect the TLR-NF-kB pathway.

\section{Conclusions}

Our data show that $\mathrm{H}_{2} \mathrm{~S}$ inhibits the activation and the nuclear translocation of the NF- $\mathrm{kB}$, reducing the transcription of pro-inflammatory genes, including MCP-1 gene.

$\mathrm{H}_{2} \mathrm{~S}$-releasing compounds are currently being developed as candidate drugs [3] and it is important to understand the $\mathrm{H}_{2} \mathrm{~S}$-mediated mechanism of action during inflammatory response to infection.

\section{Abbreviations}

$\mathrm{H}_{2} \mathrm{~S}$ : Hydrogen sulfide; NaHS: Sodium hydrosulfide; GYY4137: Morpholin4-ium-4-methoxyphenyl-(morpholino)-phosphinodithioate; NF-kB: nuclear factor-kB; M.F: Mycoplasma fermentans; MCP-1 (CCL-2): Monocyte

Chemoattractant Protein-1; MMP-12: Matrix metalloproteinase-12; TLR: Toll like receptor; MyD88: Myeloid differentiation primary response gene (88); IKK: IKB kinase; TIRAP: Toll-interleukin 1 receptor domain containing adaptor protein.
Competing interests

The authors declare that they have no competing interests.

\section{Authors' contributions}

FB designed and performed experiments, analyzed data, and wrote the manuscript; SD designed and performed experiments; SK performed experiments and contributed to the writing of the manuscript; RCG provided logistic and budget support and contributed to the writing of the manuscript; GS contributed to the writing of the manuscript; DZ provided logistic and budget support and contributed to the writing of the manuscript; SC designed and performed experiments, analyzed data, and wrote the manuscript. All authors read and approved the final manuscript.

\section{Acknowledgements}

The authors would like to thank Dr. Brian Taylor and Laura Russell for the technical support.

\section{Funding source}

This study was supported in part by the Foundation for the Scientific Thermal Research (FoRST) (Rome, Italy) grant.

\section{Author details}

${ }^{1}$ Institute of Human Virology, University of Maryland School of Medicine, Baltimore, MD 21201, USA. ²Department of Biomedical, Biotechnological and Translational Sciences (S.Bi.Bi.T.), Anatomy and Histology Unit, University of Parma, Ospedale Maggiore, 43100 Parma, Italy. ${ }^{3}$ Department of Medicine and Health Sciences, University of Molise, Campobasso 86100, Italy.

Received: 16 April 2014 Accepted: 22 May 2014

Published: 24 May 2014

\section{References}

1. Li L, Rose P, Moore PK: Hydrogen sulfide and cell signaling. Annu Rev Pharmacol Toxicol 2011, 51:169-187.

2. Predmore BL, Lefer DJ, Gojon G: Hydrogen sulfide in biochemistry and medicine. Antioxid Redox Signal 2012, 17(1):119-140.

3. Szabó C: Hydrogen sulphide and its therapeutic potential. Nat Rev Drug Discov 2007, 6(11):917-935.

4. Bian JS, Yong QC, Pan TT, Feng ZN, Ali MY, Zhou S, Moore PK: Role of hydrogen sulfide in the cardioprotection caused by ischemic preconditioning in the rat heart and cardiac myocytes. J Pharmacol Exp Ther 2006, 316(12):670-678.

5. Papapetropoulos A, Pyriochou A, Altaany Z, Yang G, Marazioti A, Zhou Z, Jeschke MG, Branski LK, Herndon DN, Wang R, Szabó C: Hydrogen sulfide is an endogenous stimulator of angiogenesis. Proc Natl Acad Sci USA 2009, 106(51):21972-21977.

6. Bucci M, Papapetropoulos A, Vellecco V, Zhou Z, Pyriochou A, Roussos C, Roviezzo F, Brancaleone $V$, Cirino G: Hydrogen sulfide is an endogenous inhibitor of phosphodiesterase activity. Arterioscler Thromb Vasc Biol 2010, 30(10):1998-2004.

7. Zhao W, Zhang J, Lu Y, Wang R: The vasorelaxant effect of $\mathrm{H}(2) \mathrm{S}$ as a novel endogenous gaseous K(ATP) channel opener. EMBO J 2001, 20(21):6008-6016.

8. Grambow E, Mueller Graf F, Delyagina E, Frank M, Kuhla A, Vollmar B: Effect of the hydrogen sulfide donor GYY4137 on platelet activation and microvascular thrombus formation in mice. Platelets 2013, 25(3):166-174. Epub ahead of print.

9. Mirandola P, Gobbi G, Sponzilli I, Pambianco M, Malinverno C, Cacchioli A, De Panfilis G, Vitale M: Exogenous hydrogen sulfide induces functional inhibition and cell death of cytotoxic lymphocytes subsets. J Cell Physio/ 2007, 213(3):826-833.

10. Fox B, Schantz JT, Haigh R, Wood ME, Moore PK, Viner N, Spencer JP, Winyard PG, Whiteman M: Inducible hydrogen sulfide synthesis in chondrocytes and mesenchymal progenitor cells: is $\mathrm{H}_{2} \mathrm{~S}$ a novel cytoprotective mediator in the inflamed joint? J Cell Mol Med 2012, 16(4):896-910.

11. Whiteman M, Winyard PG: Hydrogen sulfide and inflammation: the good, the bad, the ugly and the promising. Exp Rev Clin Pharmacol 2011, $4(1): 13-32$. 
12. Zanardo RC, Brancaleone V, Distrutti E, Fiorucci S, Cirino G, Wallace JL: Hydrogen sulfide is an endogenous modulator of leukocyte-mediated inflammation. FASEB J 2006, 20(12):2118-2120.

13. Oh GS, Pae HO, Lee BS, Kim BN, Kim JM, Kim HR, Jeon SB, Jeon WK, Chae HJ, Chung $\mathrm{HT}$ : Hydrogen sulfide inhibits nitric oxide production and nuclear factor-kappaB via heme oxygenase-1 expression in RAW264.7 macrophages stimulated with lipopolysaccharide. Free Radic Biol Med 2006, 41(1):106-119.

14. Pan LL, Liu XH, Gong QH, Wu D, Zhu YZ: Hydrogen sulfide attenuated tumor necrosis factor-a-induced inflammatory signaling and dysfunction in vascular endothelial cells. PLoS One 2011, 6(5):e19766.

15. Lee M, Schwab C, Yu S, McGeer E, McGeer PL: Astrocytes produce the antiinflammatory and neuroprotective agent hydrogen sulfide. Neurobiol Aging 2009, 30(10):1523-1534.

16. Hu LF, Wong PT, Moore PK, Bian JS: Hydrogen sulfide attenuates lipopolysaccharide-induced inflammation by inhibition of p38 mitogenactivated protein kinase in microglia. J Neurochem 2007, 100(4):1121-1128.

17. Li L, Salto-Tellez M, Tan CH, Whiteman M, Moore PK: GYY4137, a novel hydrogen sulfide-releasing molecule, protects against endotoxic shock in the rat. Free Radic Biol Med 2009, 47(1):103-113.

18. Peake BF, Nicholson CK, Lambert JP, Hood RL, Amin H, Amin S, Calvert JW: Hydrogen sulfide preconditions the $\mathrm{db} / \mathrm{db}$ diabetic mouse heart against ischemia-reperfusion injury by activating Nrf2 signaling in an Erkdependent manner. Am J Physiol Heart Circ Physiol 2013, 304(9):1215-1224.

19. Kaspar JW, Niture SK, Jaiswal AK: Nrf2:INrf2 (Keap1) signaling in oxidative stress. Free Radic Biol Med 2009, 47(9):1304-1309.

20. Merighi S, Gessi S, Varani K, Fazzi D, Borea PA: Hydrogen sulfide modulates the release of nitric oxide and VEGF in human keratinocytes. Pharmacol Res 2012, 66(5):428-436.

21. Razin S, Yogev D, Naot Y: Molecular biology and pathogenicity of mycoplasmas. Microbiol Mol Biol Rev 1998, 62(4):1094-1156.

22. Rottem S: Interaction of mycoplasmas with host cells. Physio/ Rev 2003 , 83(2):417-432

23. Seya T, Matsumoto M: A lipoprotein family from Mycoplasma fermentans confers host immune activation through Toll-like receptor 2 . Int $\mathrm{J}$ Biochem Cell Biol 2002, 34(8):901-906.

24. Kawahito $Y$, Ichinose $S$, Sano H, Tsubouchi Y, Kohno M, Yoshikawa T, Tokunaga D, Hojo T, Harasawa R, Nakano T, Matsuda K: Mycoplasma fermentans glycolipid-antigen as a pathogen of rheumatoid arthritis. Biochem Biophys Res Commun 2008, 369(2):561-566.

25. Gilroy CB, Keat A, Taylor-Robinson D: The prevalence of Mycoplasma fermentans in patients with inflammatory arthritides. Rheumatology 2001, 40(12):1355-1358.

26. Yáñez A, Martínez-Ramos A, Calixto T, González-Matus FJ, Rivera-Tapia JA, Giono S, Gil C, Cedillo L: Animal model of Mycoplasma fermentans respiratory infection. BMC Res Notes 2013, 8:6-9.

27. Afriat R, Horowitz S, Priel E: Mycoplasma fermentans inhibits the activity of cellular DNA topoisomerase I by activation of PARP1 and alters the efficacy of its anti-cancer inhibitor. PLOS One 2013, 8(8):e72377.

28. Rawadi G, Roman-Roman S: Mycoplasma membrane lipoproteins induced proinflammatory cytokines by a mechanism distinct from that of lipopolysaccharide. Infect Immun 1996, 64(12):637-643.

29. Yoshimura T, Yuhki N, Moore SK, Appella E, Lerman MI, Leonard EJ: Human monocyte chemoattractant protein-1 (MCP-1). Full-length cDNA cloning, expression in mitogen-stimulated blood mononuclear leukocytes, and sequence similarity to mouse competence gene JE. FEBS Lett 1989, 244(2):487-493.

30. Fuentes ME, Durham SK, Swerdel MR, Lewin AC, Barton DS, Megill JR, Bravo R, Lira SA: Controlled recruitment of monocytes and macrophages to specific organs through transgenic expression of monocyte chemoattractant protein-1. J Immunol 1995, 155(12):5769-5776.

31. Gu L, Tseng SC, Rollins BJ: Monocyte chemoattractant protein-1. Chem Immunol 1999, 72:7-29.

32. Sørensen TL, Ransohoff RM, Strieter RM, Sellebjerg F: Chemokine CCL2 and chemokine receptor CCR2 in early active multiple sclerosis. Eur J Neurol 2004, 11(7):445-449.

33. Hayashida K, Nanki T, Girschick H, Yavuz S, Ochi T, Lipsky PE: Synovial stromal cells from rheumatoid arthritis patients attract monocytes by producing MCP-1 and IL-8. Arthritis Res 2001, 3(2):118-126.

34. Kusano KF, Nakamura K, Kusano H, Nishii N, Banba K, Ikeda T, Hashimoto K, Yamamoto M, Fujio H, Miura A, Ohta K, Morita H, Saito H, Emori T, Nakamura Y, Kusano I, Ohe T: Significance of the level of monocyte chemoattractant protein-1 in human atherosclerosis. Circ J 2004 68(7):671-676.

35. Sartipy P, Loskutoff DJ: Monocyte chemoattractant protein 1 in obesity and insulin resistance. Proc Natl Acad Sci USA 2003, 100(12):7265-7270.

36. Lai JF, Zindl CL, Duffy LB, Atkinson TP, Jung YW, van Rooijen N, Waites KB, Krause DC, Chaplin DD: Critical role of macrophages and their activation via MyD88-NFkB signaling in lung innate immunity to Mycoplasma pneumoniae. PLoS One 2010, 5(12):e14417.

37. Rawadi G: Mycoplasma fermentans interaction with monocytes/ macrophages: molecular basis. Microbes Infect 2000, 2(8):955-964

38. Kaufmann A, Mühlradt PF, Gemsa D, Sprenger H: Induction of cytokines and chemokines in human monocytes by Mycoplasma fermentansderived lipoprotein MALP-2. Infect Immun 1999, 67(12):6303-6308.

39. Yadav A, Saini V, Arora S: MCP-1: Chemoattractant with a role beyond immunity: A review. Clin Chim Acta 2010, 411(21-22):1570-1579.

40. Dean RA, Cox JH, Bellac CL, Doucet A, Starr AE, Overall CM: Macrophagespecific metalloelastase (MMP-12) truncates and inactivates ELR + CXC chemokines and generates $\mathrm{CCL} 2,-7,-8$, and -13 antagonists: potential role of the macrophage in terminating polymorphonuclear leukocyte influx. Blood 2008, 112(8):3455-3464.

41. Li L, Whiteman M, Guan YY, Neo KL, Cheng Y, Lee SW, Zhao Y, Baskar R, Tan CH, Moore PK: Characterization of a novel, water-soluble hydrogen sulfide-releasing molecule (GYY4137): new insights into the biology of hydrogen sulfide. Circulation 2008, 117(18):2351-2360.

42. Ueda A, Ishigatsubo Y, Okubo T, Yoshimura T: Transcriptional regulation of the human monocyte chemoattractant protein-1 gene. Cooperation of two NF-kappaB sites and NF-kappaB/Rel subunit specificity. J Biol Chem 1997, 272(49):31092-31099.

43. Won K, Kim SM, Lee SA, Rhim BY, Eo SK, Kim K: Multiple Signaling Molecules are Involved in Expression of CCL2 and IL-1 in Response to FSL-1, a Toll-Like Receptor 6 Agonist, in Macrophages. Korean J Physiol Pharmacol 2012, 16(6):447-453.

44. Sacht G, Marten A, Deiters U, Submuth R, Jung G, Wingender E, Muhlradt PF: Activation of nuclear factor-kB in macrophages by mycoplasmal lipopeptides. Eur J Immunol 1998, 28(12):4207-4212.

45. Hawkins RE, Rickman LS, Vermund SH, Carl M: Association of Mycoplasma and human immunodeficiency virus infection: detection of amplified Mycoplasma fermentans DNA in blood. J Infect Dis 1992, 165(3):581-585.

46. You XX, Zeng YH, Wu YM: Interactions between mycoplasma lipidassociated membrane proteins and the host cells. J Zhejiang Univ Sci $B$ 2006, 7(5):342-350.

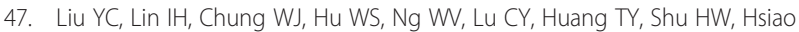
$\mathrm{KJ}$, Tsai SF, Chang CH, Lin CH: Proteomics characterization of cytoplasmic and lipid-associated membrane proteins of human pathogen Mycoplasma fermentans M64. PLoS One 2012, 7(4):e35304.

48. Bossink AW, Paemen L, Jansen PM, Hack CE, Thijs LG, Van Damme J: Plasma levels of the chemokines monocyte chemotactic proteins- 1 and -2 are elevated in human sepsis. Blood 1995, 86(10):3841-3847.

49. Tak PP, Firestein GS: NF-kB: a key role in inflammatory diseases. J Clin Invest 2001, 107(1):7-11.

50. Li Q, Verma IM: NF-kappaB regulation in the immune system. Nat Rev Immunol 2002, 2(10):725-734.

51. Baeuerle PA, Baichwal VR: NF-kB as a frequent target for immunosuppressive and anti-inflammatory molecules. Adv Immunol 1997, 65:111-137.

52. Sen N, Paul BD, Gadalla MM, Mustafa AK, Sen T, Xu R, Kim S, Snyder SH: Hydrogen sulfide-linked sulfhydration of NF-KB mediates its antiapoptotic actions. Mol Cell 2012, 45(1):13-24.

doi:10.1186/1479-5876-12-145

Cite this article as: Benedetti et al:: Sulfur compounds block MCP-1 production by Mycoplasma fermentans-infected macrophages through NF-kB inhibition. Journal of Translational Medicine 2014 12:145. 